\author{
Ahalmen espazialaren ikerketa bat Haur Hezkuntzan \\ A study of spatial ability in Chilhood Education \\ Iera Arrieta Cortajarena* \\ Hezkuntza, Filosofia eta Antropologia fakultatea \\ Euskal Herriko Unibertsitatea, Donostia
}

LABURPENA: $x$ x. mendearen erditik aurrera, azpimarratu izan da ahalmen espazialak matematikaren, eta bereziki geometriaren, ikas-irakaskuntza duen garrantzia; hori dela-eta ikertzaile asko zentratu da ahalmen espazialaren azterketan. Hala ere, ahalmen horri lotutako definizio eta kontzeptuen aniztasuna medio, ez da erraza izan ahalmen espazialean oinarritutako eredu sendo bat eraikitzea. Lan honetan enpirikoki egiaztatutako eredu teoriko bat proposatzen da, Haur Hezkuntzako ikasleen ahalmen espaziala neurtzea ahalbidetuko duena; horrela, ikasle bakoitzaren beharretara egokitutako arreta eskaini ahal izango da. Proposatutako eredu horretan oinarrituz, arloko ikerketetan horren ohikoak diren nesken eta mutilen ahalmen espazialean egon daitezkeen desberdintasun posibleak ere aztertzen dira.

GAKO-HITZAK: ahalmen espaziala, bistaratzea, geometria, adimena, Haur Hezkuntza.

ABSTRACT: Since the second half of the twentieth century the importance of the spatial ability in teaching-learning mathematics has been emphasized, especially in geometry, so many researchers have focused on its study. However, due to the diversity of definitions and concepts associated with such ability, it is not easy to set up a solid model to represent it. In this paper a theoretical model is proposed, empirically tested, that allows to evaluate the spatial ability of the students of Childhood Education in order to offer them an individualized attention. Based on the established model, the possible differences between girls and boys in spatial ability are also analyzed, so common in the literature related to this topic.

KEYWORDS: spatial ability, visualization, geometry, intelligence, childhood education.

\footnotetext{
* Harremanetan jartzeko / Corresponding author: lera Arrieta Cortajarena. Euskal Herriko Unibertsitatea. Matematikaren eta zientzia esperimentalen didaktika. Hezkuntza, Filosofia eta Antropologia Fakultatea. Oñati Plaza 3. 20018 Donostia iera.arrieta@ehu.eus - http://orcid.org/0000-0002-0244-5172
}

Nola aipatu / How to cite: Arrieta Cortajarena, lera. (2020). «Ahalmen espazialaren ikerketa bat Haur Hezkuntzan». Tantak, 32(1), 9-31. (https://doi.org/10.1387/tantak.21019).

Jasotze-data: 2019/07/18; Onartze-data: 2019/12/12.

ISSN 0214-9753 - elSSN 2444-3581 / (c) 2020 UPV/EHU

\footnotetext{
(c) (i) Obra hau Creative Commons Atribución 4.0 Internacional-en lizentziapean dago
} 


\section{MARKO TEORIKOA}

\subsection{Ahalmen espaziala}

Geometria haur txikien eguneroko esperientziatik bereizi ezin den arloa da. Beraien ingurunean mugitzerakoan eta bertan dauden objektuekin hartu-emanean ibiltzean ezagutza espazial intuitibo asko bereganatzen dute. (NCTM, 2000).

Bestalde, haurrek begien bidez jasotzen dituzte egiturak, irudiak, objektuen kokapenak eta mugimenduak. Garunak, bertan sartzen den informazio bisuala prozesatzen duen bitartean, paraleloki, entzumenari, ukimenari, usaimenari eta gorputzaren posizioari dagozkion informazioa ere prozesatzen du, baita aldez aurretik jasotako esperientzia garrantzitsuenak ere. Pertzepzio horiek guztiak haurrari kanpoko mundua eta bertako jendea nolakoa den begiztatzen laguntzen dio.

Horren harira, 0-12 urte bitartean jasaten du pertsona bakoitzak adimenean aldaketarik handiena eta, ondorioz, baita ahalmen espazialean ere. Oso garrantzitsuak dira haurrak jasotzen dituen lehenengo irudi mentalak. Bi urte dituztenetik hasten dira behatutakoa barneratzen; sei urte baino gutxiagoko haurrak behaketetatik bizi dira. (Canals, 1997).

Ildo beretik, hainbat ikertzailek (Clements, Battista, Sarama eta Swaminathan, 1997; Del Grande, 1987) esaten dutenaren arabera, haurren lehendabiziko portaeraren zati nagusietariko bat espaziala da, ingurunearen behaketetatik ikasten dutelako, hizkuntzaren laguntzarik gabe.

Ahalmen espazialean zentratuz, Vereecken-ek (1961) kontzeptuak bi mailatan sailkatzen ditu:

1. Haurraren lehenengo hilabeteetan pertzepzio espazialeko ezaugarri batzuk dagoeneko antolatuta daude; gertutasunaren pertzepzioa (adibidez, amaren aurpegian begia sudurretik gertu dago), banaketa, segida eta jarraitutasuna. Sei hilabeteren ondoren pertzepzio espazialeko ezaugarriak garatuago daude, objektuen norabidea atzematen baitu (alde batean ala bestean dagoen) eta, baita, zer distantziatara dauden ere; haurrak objektuen arteko erlazio espazial batzuk erabiltzen ditu eta formak bereizteko gai da.

2. Bigarren mailan objektuen norabide bertikala hautemateaz gain, haurra lerro bertikal bat marrazteko edo goraka mugitzen den zerbait adierazteko gai da; objektuen arteko distantziak desberdintzen ditu eta gai da gertuena zein dagoen esateko ere; objektuen arteko erlazio espazialak bereganatzen ditu, formak bereizten ditu eta horiek marrazteko gai da, berdinak diren ala ez zehaztuz.

Vurpillot-en (1976) iritziz, irudia eta hondoaren bereizketa berehala agertzen da haurrengan; beraz, jaiotzetikoa da. Haren ustetan haurrak urte 
eta erdi dituenetik estimulu bisualak pertzeptiboki antolatzen ditu. Baina 3-4 urteko haurrak identifika eta manipula ditzakeen lehenengo pertzepziozko unitate horiek, zurrunak, zatitu ezin daitezkeenak eta bata bestarekin egokitu ezin daitezkeenak direla dirudite. 6-8 urteko haurrarentzat, ordea, pertzepziozko egiturek beren zurruntasunaren zati handi bat galtzen dute.

Bestalde, Piaget (1954) da geometriaren eta ahalmen espazialaren garapena adin horietako haurrengan gehien aztertu duen ikertzaileetariko bat. Hala ere, ez zen zehazki ahalmen espazialeko gaitasunak definitzeaz ezta zenbakitzeaz arduratu. Frostig eta Horne (1964) izan ziren lehenengoak gaitasun horiek identifikatzen. Beraien aburuz, ahalmen espazialaren eraginkortasunak haurrari modu askotan laguntzen dio: irakurtzen, idazten, eragiketa aritmetikoak egiten eta, orokorrean, eskolako jardueretan arrakasta handiagoa lortzeko beste hainbat gaitasun garrantzitsu garatzen. Eta ahalmen espazial horren garapen maximoa, normalean, 3 urte eta 7 urte eta erdi bitartean lortzen dela diote.

Ondorioz, oso garrantzitsua da haurren geometriaren ikaskuntza balioztatzea. Nahiz eta haurra bere kabuz nozio espazial ugari bereganatzeko gai izan, ezinbestekoa da eskolan egiten den lana.

Ikus dezagun, beraz, ahalmen espaziala Haur Hezkuntzan nola lantzen den eta zenbateko presentzia duen.

Aurretik aipatu den bezala, haurrak eskolara espazioaren ideia intuitibo asko jasota iristen dira, beraien inguruneko esperientzia gehienak espazialak izan direlako. Modu naturalean egokitzen dira jarduera espazialetara, eta material manipulagarriak eta bizi diren espazioko objektuak erabiltzen dituzten jardueretatik, psikologikoki eta matematikoki, etekina ateratzen dute.

Desplazatzeko eta biratzeko funtsezko ideiak oinarrizkoak dira edozein haurren esplorazio espazialean; ideia horiek geometriaren testuinguruan ezartzeak abiapuntua izan behar du haurren lehenengo eskola urteetako garapen matematikoan (Newcombe, 2010).

Del Grande-ren (1987) iritziz, ahalmen espaziala garrantzitsua da ikasketen hasieran arrakasta edukitzeko eta, gainera, haurraren egonkortasunean eragin zuzena duela azpimarratzen du. Ondorioz, geometriako curriculuma osatzen dutenek kontuan hartu beharko lukete haurren espazioaren ulermenaren garapena eta informazio bisualaren tratamendua. Gainera, ahalmen espaziala ez da beharrezkoa soilik aurrezagutzak asimilatzeko eta erabiltzeko, ezagutza berrien garapenerako ere ezinbestekoa da (Kell, Lubinski, Benbow eta Steiger, 2013).

Azken urteetan egin diren zenbait ikerketak (Goldsmith, Hetland, Hoyle eta Winner, 2016; Hawes, Moss, Caswell eta Poliszczuk, 2015; Verdine, Golinkoff, Hirsh-Pasek eta Newcombe, 2014) ziurtatzen dute geometria eta ahalmen espazialari lotuta dauden hezkuntza-planek mesede egiten dietela beste diziplinak garatzeko orduan. 
Ildo horretan egindako zenbait ikerketak baieztatzen dute, gainera, jarduera geometriko eta espazialak Haur Hezkuntzako ikaskuntza planetan sartu beharko liratekeela, jarduera horiek egokiak eta motibagarriak direlako, eta ikasleek bereganatutako kontzeptu aritmetiko eta espazial/geometrikoak lortzeko garapenean eragiten dutelako (Cheng eta Mix, 2014).

Horretaz guztiaz gain, ikerketa ugarik azpimarratu dute espazioaren eta matematikaren arteko erlazio zuzena Haur Hezkuntzan (Gunderson, Ramirez, Beilock eta Levine, 2012; Lauer eta Lourcon, 2016); ondorioz, ezinbestekoa izan daiteke ahalmen horren esku-hartze goiztiar bat ikaskuntza matematikoan egon daitezkeen zenbait hutsune konpontzeko (Mix eta Cheng, 2012). Modu horretan, pentsamendu espazial eta geometrikorako adierazpenezko konpetentziak eta baliabideak bereganatzen dituen haurrak edozein eskola-jarduerarako gaitasun hobeak bereganatuko ditu.

\subsection{Nesken eta mutilen ahalmen espazialaren arteko desberdintasunak}

Historikoki, ikerkeketek nesken eta mutilen ahalmen espazialean, eta haien gaitasun batzuetan, desberdintasunak antzeman dituzte, betiere mutilen alde. (Battista, 1990; Linn eta Petersen, 1985; Maccoby eta Jacklin, 1974).

Azken urteetako ikerketetan emaitza kontrajarriak lortu dira: alde batetik, autore batzuek frogatu dute hezkuntza-maila desberdinetako nesken eta mutilen arteko desberdintasun horiek desagertuz joan direla (Arrieta, 2006; Frick, Hansen eta Newcombe, 2013; Lehmann, Jansen eta Quaiser-Pohl, 2014), eta beste batzuek, berriz, mutilen aldeko desberdintasun esanguratsuak daudela baieztatu dute (Ganley, Vasilyeva eta Dulaney 2014; Lauer, Udelson, Jeon eta Lourenco, 2015; Martin, Mullis eta Stanco, 2012).

Gai honen inguruan haur txikiekin egin diren azken urteetako ikerketetan zentratuz, zenbait ikerketak mutilen aldeko desberdintasun esanguratsuak nabarmendu dituzte errotazio mentalean, aurrerago aztertuko den Carroll-en ereduko Erlazio espazialaren baliokidea dena (Quinn eta Liben, 2014); beste ikertzaile batzuek, ordea, desberdintasunik ez dagoela baieztatu dute. (Möhring eta Frick, 2013; Schwarzer, Freitag, Buckel eta Lofruthe, 2013).

Ikusten denez, ikerketa horien guztien emaitzak ez datoz bat, ziur aski lan horietan ez dutelako ahalmen espazialaren eredu osatu bat aurkezten eta, sarritan, gaitasunak bakarka neurtzen direlako, ahalmen espazialaren egituran non kokatzen diren zehaztu gabe. Horrek guztiak baieztatzen du Ahalmen Espazialaren eredu teoriko sendo eta bateratu baten beharra. 


\subsection{Eredu teorikoa}

Ahalmen espaziala eguneroko bizitzako arlo askotan erabiltzen da eta, horrexegatik, hainbat diziplinatako ikertzaileek aztertu dute, helburu desberdinekin. (Maris eta Noriega, 2010; Sarasua, 2010; Uttal, Meadow, Tipton, Hand, Alen, Warren eta Newcombe, 2013). Hainbat ikertzailek hitz desberdinak erabili dituzte kontzeptu berbererako (arrazonamendu espaziala, ahalmen espaziala, pentsamendu espaziala, bistaratzea...) eta beste batzuek, ordea, hitz berbera esanahi desberdinekin. Beraz, garrantzitsua da kontzeptuak zorroztasunez definitzea eta erabiltzen diren hitzak eta adierazpenak batzen saiatzea.

Ikerketa honetan «ahalmen espaziala» erabili da, Hezkuntza Matematikoan gehien erabiltzen den adierazpena delako eta oinarri teoriko handiena duelako; eta Arrietak (2006, 108. or.) proposatutako definizioa hartu da aintzat: «irudiak eta objektuak mentalki identifikatzeko eta manipulatzeko gaitasuna».

Ikas-irakaskuntza prozeduretan garrantzitsua da zehaztea ahalmen espazialaren zein alderdi hobetu daitezkeen eta, aldi berean, zehaztea nola hobekuntza horiek STEM diziplinen ikaskuntza erraztu dezaketen. Ildo horri jarraiki, ahalmen espazialaren malgutasunari buruzko ikerketa garrantzitsu bat burutu dute Uttal, Miller eta Newcombe (2013) ikertzaileek: 25 urtean (1984-2009) egindako ikerketen meta-analisi bat egin dute, esku-hartze espazialaren eraginaren tamaina zehazteko. Horixe da gai honi buruz egindako lehenengo meta-analisi zehatz eta osoa. Hauexek dira emaitza esanguratsuenak: a) aztertutako esku-hartze metodo guztiekin ahalmen espazialean hobekuntza esanguratsuak lortu dira; b) adinarekiko ez dago desberdintasun esanguratsurik; c) neskek eta mutilek lortzen dituzte hobekuntza esanguratsuak. Lan horretan ahalmen espaziala lantzearen garrantzia azpimarratzen da. Hala ere, gaitasun espazialak eredu teoriko finko batean oinarritu gabe sailkatzen dira, eta horrek zailtzen du beste ikerketa batzuekin konparaketak egitea.

Beraz, ezinbestekoa da lehendabizi ahalmen espaziala neurtzea ahalbidetuko duen eredu teoriko sendo bat zehaztea; eredu horrek, ondoren, ahalmen espaziala hobetzeko egokiena izan daitekeen esku-hartze espaziala zehazten lagundu dezake eta, ondorioz, baita matematikako (eta beste diziplinetako) errendimendua hobetzen ere.

Has gaitezen, beraz, Haur Hezkuntzako ikasleen ahalmen espazialaren eredu teorikoaren azterketarekin.

Aurretik aipatu den bezala, haur txikien ahalmen espazialaren inguruan ikerketa gutxiago dago gazteen ahalmen espazialaren azterketekin alderatuz gero, eta ez dago eredu teoriko finkorik. Hala ere, hainbat ikertzailek bide interesgarriak ireki dituzte eta horietan oinarrituko gara lan hau bideratzeko.

Frostig eta Horne (1964) izan ziren haurren ahalmen espazialeko gaitasunak zerrendatu zituzten lehenengoak; eredu hori beste ikertzaile batzuek ere baieztatu eta erabili dute. (Cunningham eta Reagan, 1972; Del Grande, 
1987; Martin, 2006; Sarasua, 2010). Ikus ditzagun, beraz, Frostig eta Horne-ren (1964) arabera zein diren ahalmen espazialaren gaitasun nagusiak:

- Bisomotrizitate koordinazioa. Gorputzeko (edo gorputzeko zatien) mugimenduak ikusmenarekin koordinatzeko ahalmena. Adibidez, pertsona batek altzarietatik hautsa kentzean, ikusmenak gidatzen ditu haren eskuak.

- Irudi-hondoaren pertzepzioa. Atentzioa estimulu egokitan zentratzeko haurrak duen ahalmena, hau da, hondo konplexu batean irudi jakin bat identifikatzeko ekintza bisuala. Adibidez, haur bat baloiarekin jolasten ari da parkean. Haurrak bere interesa baloian zentratzen du, eta hori izango da, beraz, jasotzen duen eszenaren barneko irudia. Baina parkean jolasak, loreak, aulkiak... daude haurraren interesa pizten ez dutenak eta aipatutako hondoa osatuko dutenak.

- Iraunkortasun pertzeptuala. Objektu batek propietate aldagaitzak (forma, posizioa eta neurria) dituela antzemateko gaitasuna; hau da, espazioan irudiak edo objektuak antzemateko gaitasuna, irudiaren dimentsioa, posizioa edo orientazioa edozein izanda ere. Aurreko adibidearekin jarraituz, haurrak baloiaren tamaina ongi ezagutzen badu eta iraunkortasun pertzeptual egokia badu, baloiak, urrun egonda ere, tamaina bera duela ohartuko da, nahiz eta begiz baloia txikiagoa ikusten duen.

- Espazioko posizioaren pertzepzioa. Behatzaileak objektu batekiko duen erlazioa espazioan. Espazialki, pertsona bakoitza bere mundu propioaren zentroa da eta bere atzean, aurrean, goian, behean edo alboan dauden objektuak antzematen ditu.

- Erlazio espazialen pertzepzioa. Behatzaileak bi edo objektu gehiagoren posizioa antzemateko gaitasuna, bai berarekiko eta baita bata bestearekiko ere.

Bestalde, Canals-ek (1997) geometriarekin zerikusia duten espazioko elementuak zein diren aztertu zuen; hiru mailatan banatu zituen: posizioa, forma eta posizioaren edo formaren eraldaketak. Lehenengo biek (posizioa eta forma) zerikusi zuzena dute ahalmen espazialarekin, baina eraldaketek, ez.

Posizioen artean aztertutako kontzeptuak ondorengoak ziren: erlazio espazialak (norberarekiko kokapena eta objektuekiko kokapena), posizioarekiko erlazioak, eta distantziak eta angeluak (erreferentzia-sistemak). Hiru gaitasun horiek Frostig eta Horne-k (1964) proposaturiko azken bi ahalmenekin erabat erlazionatuta daude, espazioko posizioaren pertzepzioarekin eta erlazio espazialen pertzepzioarekin, hain zuzen. Beraz, horien garrantzia azpimarratuta geratzen da berriz ere.

Formetan aztertutako kontzeptuak, berriz, hurrengoak izan ziren: 2 eta 3 dimentsioko irudien ezaguera, definizioa eta sailkapena, solido ezagunen eraikuntza, eta solidoen propietateen azterketa eta sailkapena. Gaitasun horiek Frostig eta Horne-k (1964) proposatutakoen hirugarren ahalmenare- 
kin, iraunkortasun pertzeptualarekin, dute lotura; eta, ondorioz, gaitasun hori ere indartuta gelditzen da.

Era berean, National Council of Teachers of Mathematics-ek (NCTM, 2000) ere, 0tik 6 urte bitarterainoko haurrek ezagutu beharreko ahalmen espazialeko kontzeptuen zerrenda bat osatu du, bi arlotan banatuta: a) erlazio espazialak, eta b) bistaratzea.

Erlazio espazialetan aipatzen dituzten kontzeptuek (goia, behea, gertu, artean) Canals-ek (1997) posizioaren arloan aipatutakoekin erabateko lotura dute eta, beraz, baita Frostig eta Horne-ren azken bi gaitasunekin ere.

Bistaratzean, berriz, hiru gaitasun zerrendatzen dituzte: a) oroimena eta ahalmen espaziala erabiliz figura geometrikoen irudi mentalak sortzea, b) perspektiba ezberdinetatik figurak ezagutzea eta marraztea, eta c) forma eta egitura geometrikoak antzematea eta beraien kokapena zehaztea. Hiru horietatik azkenengoak du lotura lehen Canals-en zerrendan aipatutako formen kontzeptuekin, eta baita Frostig eta Horne-ren hirugarren gaitasunarekin ere. Beste biak orain arte ez dira aipatuak izan, seguruenik, ahalmen horien garapena zailagoa denez, beranduen lortzen direnak direlako (4-6 urtetik aurrera) eta beste ikertzaileek horiek baino haur txikiagoen azterketa egin dutelako soilik.

Ikusitakoaren arabera, Frostig eta Horne-k (1964) egindako zerrendatik Iraunkortasun Pertzeptuala, Espazioko Posizioaren Pertzepzioa eta Erlazio Espazialen Pertzepzioa gaitasunek justifikazio nahikoa dutela ondoriozta daiteke. Hala ere, ikertzaile gehiago ere badira horiek aipatzen dituztenak; adibidez, Vereecken (1961) eta Vurpillot-ek (1976) gaitasun horiek zehaztasun handiagoz aztertzen dituzte aurrean/atzean, goian/behean, ezkerraldean/eskuinaldean eta gertu/urrun/artean kontzeptuak erabiliz.

Horretaz gain, Hoffer-ek (1977) Frostig eta Horne-ren (1964) ereduko bost gaitasun horiei beste bi gehitu zizkien: Bereizketa Bisuala eta Oroimen Bisuala; eta beraz, berak zazpi gaitasuneko eredua osatu zuen. Del Grande-k (1987) eta Gutierrez-ek (1991) ere Hoffer-en eredu hori berretsi zuten. Azter ditzagun zehatzago bi gaitasun berriak:

- Bereizketa bisuala. Objektuen ezaugarrien arteko berdintasunak eta desberdintasunak bereizteko gaitasuna; posizioarekiko independentea da. Haurrek marrazkiak erabil ditzakete faktore hau lantzeko, bertan ikusten dutenaren arteko konparaketa bisualak eta ahozkoak eginez.

- Oroimen bisuala. Denbora laburrean ikusitako objektu bat zehazki gogoratzeko eta bistan dauden (edo ez) beste objektu batzuekin konparatuz berdintasunak eta desberdintasunak antzemateko gaitasuna. Pertsona gehienak gai dira oroimenean informazio bisual kopuru txikia (5-7 objektu) gordetzeko epe labur batean. Baina informazio kopuru handia jasotzeko, informazioa epe luzerako oroimenean gorde behar da abstrakzioaren eta pentsamendu sinbolikoaren bidez. Gaitasun hori oso garatua duen pertsona batek «oroimen fotografikoa» duela esaten da. 
Ondorioz, eredu teorikoa finkatzen hasteko, Hoffer-ek proposatutakoa hartuko dugu aintzat:

1. Bisomotrizitate-koordinazioa.

2. Irudi-hondoaren pertzepzioa.

3. Iraunkortasun pertzeptuala.

4. Espazioko posizioaren pertzepzioa.

5. Erlazio espazialen pertzepzioa.

6. Bereizketa bisuala.

7. Oroimen bisuala.

Baina, alde batetik, Frostig eta Horne-ren eredua berresteko erabilitako ikertzaileek ez dute Bisomotrizitate koordinazioa aipatzen. Vurpillot-ek (1976) esaten duenez, gaitasun hori haurrak bi hilabete dituenetik hasten da bereganatzen, eta denbora aurrera joan ahala, begien desplazamendu-mugimenduak geroz eta azkarrago egiten dira. Gainera, haurren ahalmen espaziala ikertu duten egile askok ere ez dute gaitasun hori aipatzen (Canals, 1997; Gutierrez, 1991; NCTM, 2000), ikertzaile horietako batzuen iritziz, haurrek oso txikitatik bereganatzen duten gaitasuna delako, eta besteen iritziz, berriz, ez duelako jarduera geometrikoekin erlazio zuzenik.

Beraz, ikerketa honetan 5-6 urteko haurrak aztertzen direnez, ez du zentzurik gaitasun hori lantzeak, adin horretarako dagoeneko bereganatuta edukiko baitute.

Oroimen bisualari dagokionez, Gutierrez-en (1991) ustez, gai psiko-fisiologikoa nagusitzen da eta ez du lotura zuzena ahalmen espazialarekin.

Bestalde, Carroll-ek (1993) adimena osatzen duten gaitasun guztien azterketa sakona egin zuen analisi faktoriala erabiliz (12 urtetik gorako ikasleentzat). Berak lortutako eredu horretan, adimena 8 faktore independentetan banatzen da, eta horietariko bat ahalmen espaziala da eta, bestea, oroimenaren gaitasuna. Carroll-ek, bere analisi faktorialarekin, ziurtatu zuen oroimen bisuala oroimenaren faktoreetariko bat dela, ahalmen espazialarekiko independentea dena. Horren ondorioz, oroimen bisuala ezin da ahalmen espazialaren faktore moduan aurkeztu.

Aurreko guztia kontuan hartuz, 5 eta 6 urte bitarteko haurrek lortu beharreko gaitasunak, eta euren ahalmen espaziala neurtzeko erabiliko ditugunak, ondokoak dira (Frostig eta Horne, 1964; Hoffer, 1977):

1. Irudi-hondoaren pertzepzioa. Atentzioa estimulu egokitan zentratzeko haurrak duen ahalmena.

2. Iraunkortasun pertzeptuala. Objektu batek propietate aldagaitzak (forma, posizioa eta neurria) dituela antzemateko gaitasuna.

3. Espazioko posizioaren pertzepzioa. Behatzaileak objektu batekiko duen erlazioa espazioan.

4. Erlazio espazialen pertzepzioa. Behatzaileak bi edo objektu gehiagoren posizioa antzemateko gaitasuna, bai berarekiko eta baita bata bestearekiko ere. 
5. Bereizketa bisuala. Objektuen arteko berdintasunak eta desberdintasunak bereizteko gaitasuna.

Bestalde, aurretik aipatutako Carroll-en (1993) ereduak ordura arte egindako ikerketa gehienak beregain hartzen ditu, eta analisi faktorialaren bidezko justifikazio enpirikoa duen eredu bakarra da harena. Carroll-ek Adimen Orokorra eta, zehazki, Ahalmen Espaziala (Pertzepzio Bisuala moduan adierazten duena) modu honetan banatzen du (ikus 1. irudia).

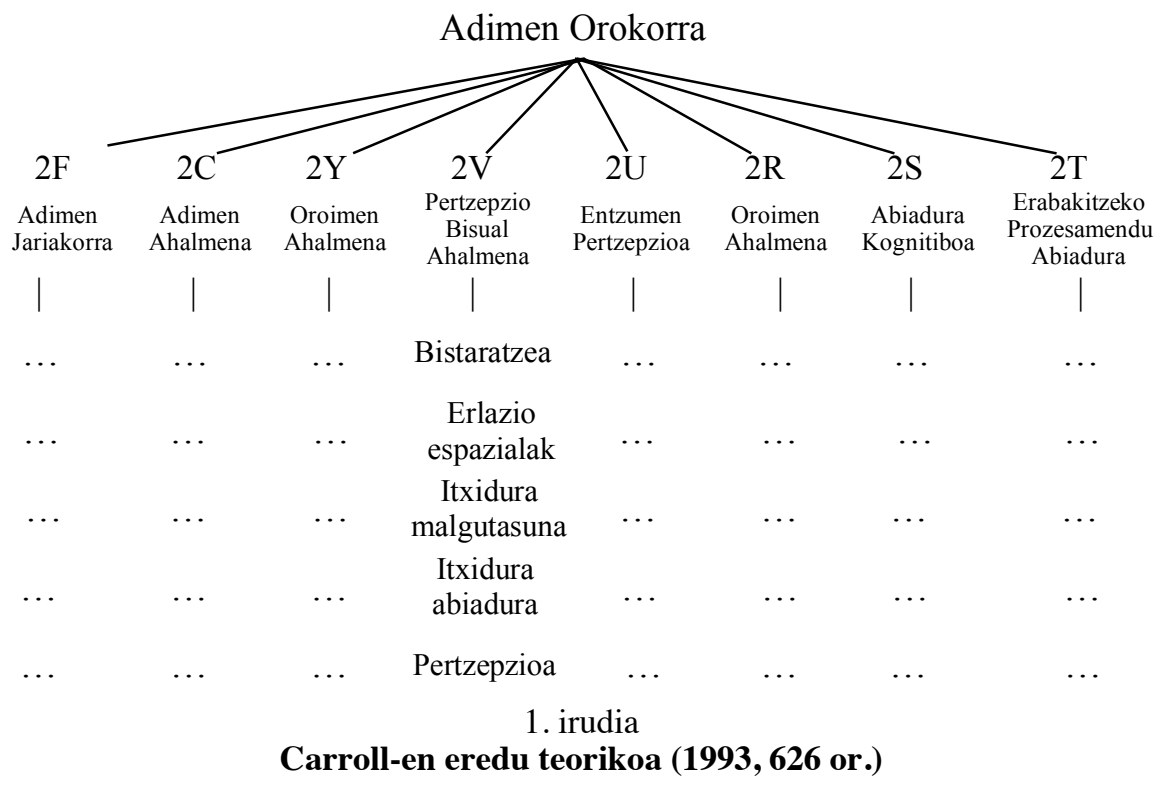

Lehenengo geruzan oinarrizko gaitasun zehatzak daude, ondorengo geruzako eremu kognitibo bakoitza osatzen dutenak; pertzepzio bisualean (ahalmen espazialean) zehazki, bistaratzea, erlazio espazialak, itxidura malgutasuna, itxidura abiadura eta pertzepzio abiadura daude, beraien artean independenteak direlarik.

Ikerketa ugaritan orientazio espaziala ahalmen espazialaren parte den faktore bezala hartu izan ohi da. Adibidez, Bishop-ek (1983) eta Tartre-k (1990) matematikaren hezkuntzaren ildotik egindako ikerketek orientazio espaziala bistaratzearen eta erlazio espazialen desberdina den faktore bezala hartu zuten. Carroll-en arabera, ordea, orientazio espaziala ezin da aurreko bi faktore horietatik bereizi, ahalmen espazialaren konfigurazioan duen pisu faktoriala beste bi horien pisuekin ezeztatuta geratzen baita.

Carroll-ek proposatutako eredua 461 ikerketatan lortutako emaitzetan oinarritzen da; eta beraz, ereduak duen oinarri enpirikoa ukaezina da. $3 \mathrm{G}$ 
(Spearmean-en «g» faktorea) 36 aldiz erreplikatua izan da hirugarren faktore bezala eta horrek berresten du ereduak daukan babes enpirikoa.

Carroll-en ereduko ahalmen espazialeko faktoreei lotutako probei dagokienez, Bistaratzeak (SR), Itxidura Malgutasunak (CF) eta Erlazio Espazialek (SR) zailtasun maila handiagoa dute beste biekin alderatuz gero; horrexegatik, 11-12 urte edo gehiago dituzten haurrek egiteko modukoak dira (Arrieta, 2006). Bickley, Keith eta Wolfle-k (1995) ere bi faktore (CS eta $\mathrm{P}$ ) bakarrik erabili zituzten 12 urte baino gutxiagoko haurren ahalmen espaziala lantzeko, besteak (VZ, CF eta SR) konplexuegiak zirela baieztatuz; gauza berbera egin zuten lehenengo ordenako faktore bakoitzarekin. Murrizketa hori gauzatu arren, aipatutako ikertzaileek Carroll-en ereduko bi alderdi garrantzitsuenak baieztatu zituzten: alde batetik, adimena hiru geruzatan banatzen dela eta bertan ahalmen espazialak kokaleku garrantzitsua duela eta, bestetik, adimenaren antolaketa bizi-ziklo osoan mantentzen dela.

Ikus ditzagun bada, autore horiek erabilitako ahalmen espazialeko bi faktoreen definizioak:

- Itxidura abiadura (CS). Bestelakoa dirudien pertzepzio eremu bat irudi bakar batean lotzeko azkartasuna. Hau da, osatu gabe edo hondatuta, lausotuta edo ilunduta aurkeztutako eredu bat identifikatzea. Ereduak irudi ezagun bat izan behar du; eta izendatuz identifikatu behar da irudia, aldizkako aukerak eskaintzeak pista gehiegi ematen baitu.

- Pertzepzio abiadura (P). Eredu ezagun bat aurkitzeko azkartasuna edo eredu bat edo gehiago zehazki konparatzeko azkartasuna. Bi motatako galdetegiak daude: alde batetik, letrak azkar aurkitzekoak eta, bestetik, aurpegiak, formak eta izenak azkar konparatzeko galdetegiak. Hoffer-en (1977) Bereizketa Bisualaren baliokidea dela argi ikusten da bien definizioak aintzat hartuta.

Aurretik ikusi dugunez, Bickley, Keith eta Wolfle-k (1995) Carroll-en (1993) eredu murriztua erabili zuten 6 eta 12 urte bitarteko haurrekin, bost faktoreetatik bi bakarrik kontuan hartuz. Beraz, garrantzitsua izango da atal honetan aztertutako bi ereduak (Frostig eta Horne-ren (1964) eredu egokitua eta Carroll-en eredu murriztua) konparatzea eta baliokideak ote diren ikertzea, 5-6 urteko haurren ahalmen espazialerako eredu teorikoaren proposamen finko bat eman ahal izateko.

\section{HELBURUAK}

Lan honen helburu nagusia 5-6 urteko haurren ahalmen espazialaren eredu teoriko bat proposatzea da, Haur Hezkuntzako ikasle bakoitzaren beharretara egokitutako arreta eskaini ahal izateko. 
Ikerketaren helburu zehatzak ondokoak dira:

1. Aurretik aipatutako bi ereduen arteko baliokidetasuna aztertzea. Alde batetik, Frostig eta Horne-ren (1964) eredu egokituan oinarritutako galdetegiak pasatuko dira; bestetik, Carroll-en (1993) eredu murriztuan oinarritutako galdetegiak pasatuko dira. Galdetegietan lortutako emaitzekin bi ereduak baliokideak diren ala ez ondorioztatuko da.

2. Ahalmen espazialean egon daitezkeen sexu desberdintasunak aztertzea.

Ikerketa ugarik baieztatu dute nesken eta mutilen ahalmen espazialean, eta bere faktoreetako batzuetan, desberdintasun esanguratsuak daudela. Lan honetan hori betetzen den ala ez aztertuko da.

\section{METODOLOGIA}

\subsection{Lagina}

Haur Hezkuntzako ikasleen ahalmen espaziala aztertzeko, Gipuzkoako bi ikastola aukeratu dira. Eskola horiek aukeratzeko orduan, ikastetxearen ikasle kopurua hartu da kontuan, lagina ahalik eta heterogeneoena izan zedin; hau da, ikastetxe handi bat eta eskola txiki bat. Gainera, galdetegi batzuk bakarka pasatu behar zirenez, eta horrek suposatzen duen lan-karga kontuan hartuta, 100 ikasle inguruz osatutako lagina nahi genuen gehienez. Irizpide horiek kontuan hartuta, bi ikastetxeak komenentziaz aukeratu dira. Alde batetik, Zarauzko Salbatore Mitxelena Ikastola, maila bakoitzean 3 edo 4 lerro baititu eta, bestetik, Anoetako Herri Ikastola aukeratu da, maila guztietan lerro bakarra baitu. Guztira, 97 haurrei pasatu dizkiegu galdetegiak (ikus 1. taula).

\section{1. taula}

\section{Laginaren banaketa}

\begin{tabular}{c|c|cccc}
\hline Ikastetxea & Herria & Lerroa & Neskak & Mutilak & N \\
\hline & & A & 9 & 11 & 20 \\
Salbatore & \multirow{2}{*}{ Zarautz } & B & 9 & 8 & 17 \\
Mitxelena & & C & 10 & 10 & 20 \\
& & D & 10 & 10 & 20 \\
\hline Herri ikastola & Anoeta & - & 6 & 14 & 20 \\
\hline \multicolumn{2}{c}{ GUZTIRA } & & 44 & 53 & 97 \\
\hline
\end{tabular}




\subsection{Aldagaiak eta galdetegiak}

Frostig eta Horne-ren (1964) eredu egokiturako erabilitako aldagaiak eta galdetegiak ondorengoak dira:

1. Irudi-hondoaren pertzepzioa (IHP). Hondo konplexu batean irudi jakin bat identifikatzeko ekintza bisuala. Frostig-ek (1988) sortutako eta balidatutako galdetegia erabili da gaitasun honen neurketarako: aukeratutako galdetegiak geroz eta hondo konplexuagoak dituzten marrazkietan irudi jakin batzuk bereiztean datza eta 8 item ditu. Ikasleek item bakoitzean irudi jakin bat urdinez markatu behar zuten (adibidez, ilargia beheko irudian).

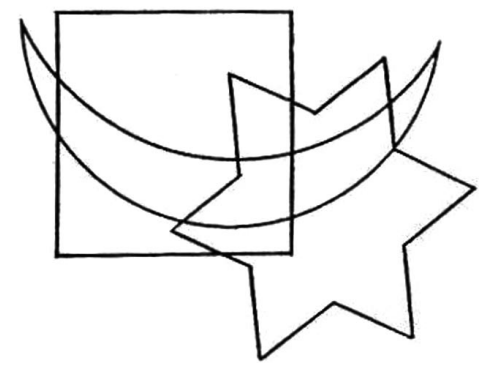

2. irudia

Irudi-hondoaren pertzepzioko galdetegiko ítem bat

(Frostig, 1988)

2. Iraunkortasun pertzeptuala (CF). Espazioan irudiak edo objektuak antzemateko gaitasuna, irudiaren dimentsioa, posizioa edo orientazioa edozein izanda ere. Frostig-ek (1988) sortutako eta balidatutako galdetegia erabili da: tamaina, posizio edota orientazio desberdinetako irudi geometriko jakin batzuk identifikatzean datza eta 32 item ditu. Ikasleei, lehendabizi zirkunferentziaren eta karratuaren irudiak erakutsi zitzaizkien. Beheko irudietan topatzen zituzten zirkunferentzia guztiak urdinez markatu behar zituzten eta, ondoren, karratuak gorriz. 

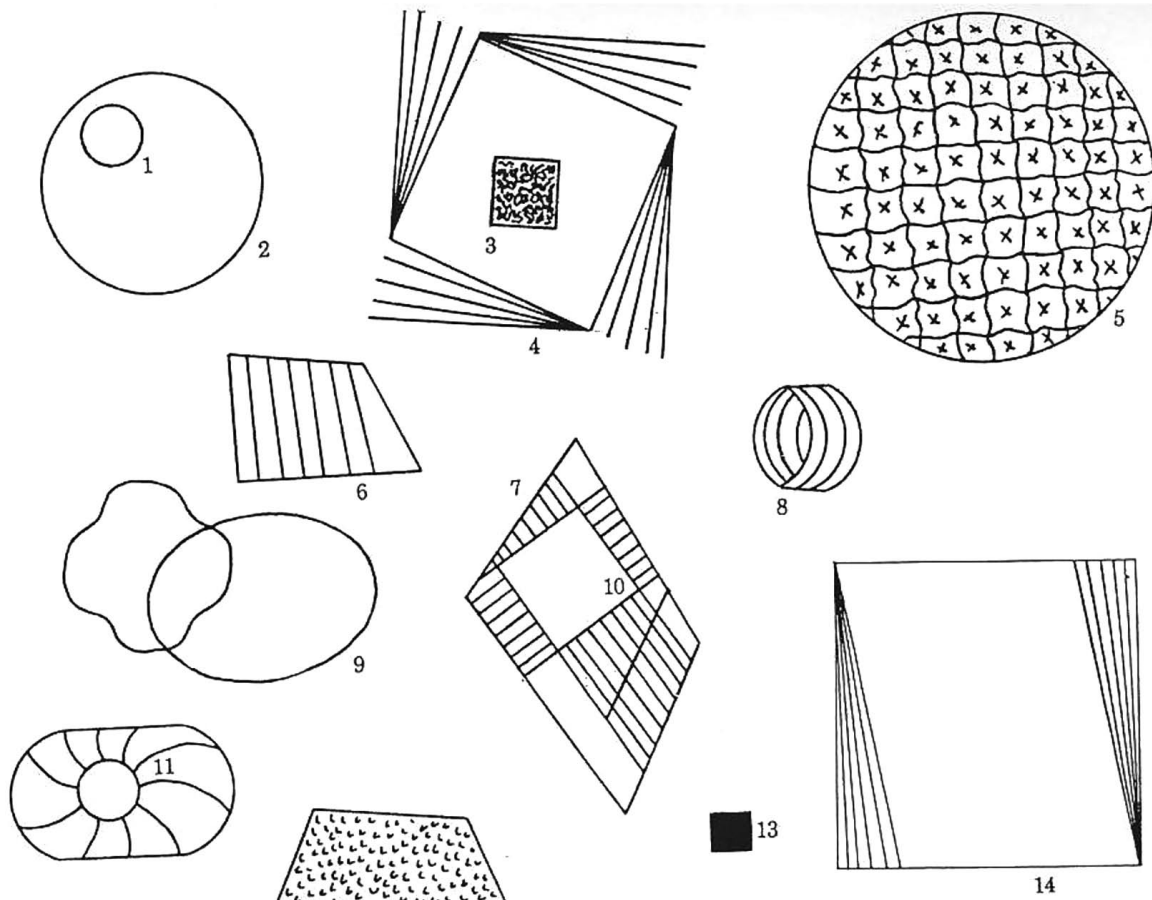

3. irudia

Iraunkortasun pertzeptualeko galdetegiko zenbait item (Frostig, 1988)

3. Espazioko posizioaren pertzepzioa (EPP). Behatzaileak objektu batekiko duen erlazioa espazioan. Frostig-ek (1988) sortutako eta balidatutako galdetegia erabili da: irudi berdinez osatutako serie batean posizio desberdinean dauden irudiak identifikatzean datza eta 8 item ditu. Ikasleek item bakoitzean bost irudietatik desberdina dena borobildu behar zuten.
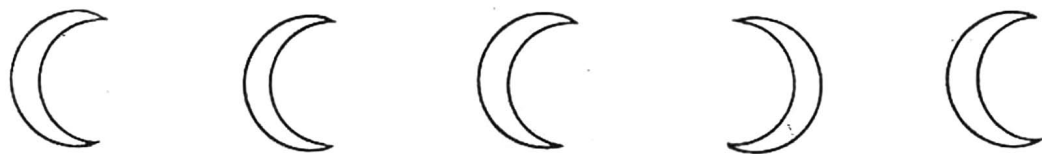

4. irudia

Espazioko posizioaren pertzepzioko galdetegiko item bat (Frostig, 1988) 
4. Erlazio espazialen pertzepzioa (EEP). Behatzaileak bi edo objektu gehiagoren posizioa antzemateko gaitasuna, bai berarekiko eta baita bata bestearekiko ere. Frostig-ek (1988) sortutako eta balidatutako galdetegia erabili da: geroz eta konplexuagoak diren zuzenkiz eta angeluz osatutako irudi baten kopia egitean datza eta 8 item ditu. Ezkerraldean ikusten den irudia eskuinaldean egiteko eskatu zitzaien ikasleei.
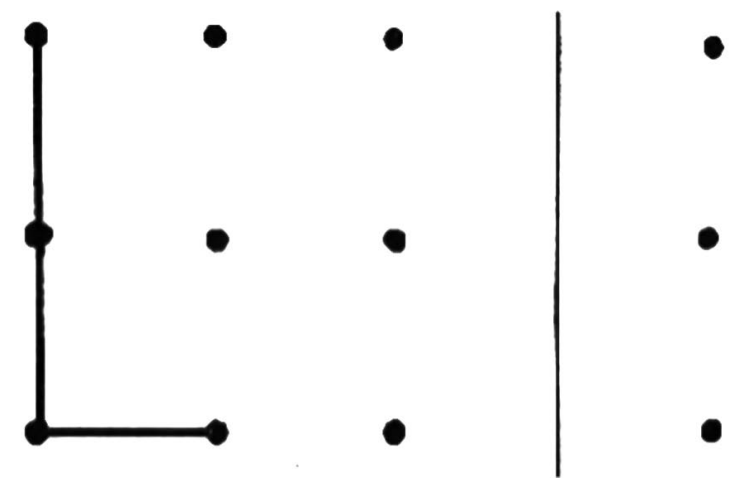

5. irudia

Erlazio espazialen pertzepzioko galdetegiko item bat

(Frostig, 1988)

5. Bereizketa bisuala (BB). Objektuen arteko berdintasunak eta desberdintasunak bereizteko gaitasuna. Aurretik aipatu den bezala eredu baten Bereizketa bisuala (BB) eta bestearen Pertzepzio abiadura (P) baliokideak dira eta, beraz, galdetegi bakarra erabili da. Martin-ek (2006) sortutako eta balidatutako galdetegia erabili da gaitasun hau neurtzeko: antzekoak diren irudien artetik ereduaren berdina den irudia identifikatzean datza eta 16 item ditu. Goian dagoen ereduaren berdina zein den esan behar zuen ikasleak eta hatzarekin seinalatu behar zuen erantzun zuzena.

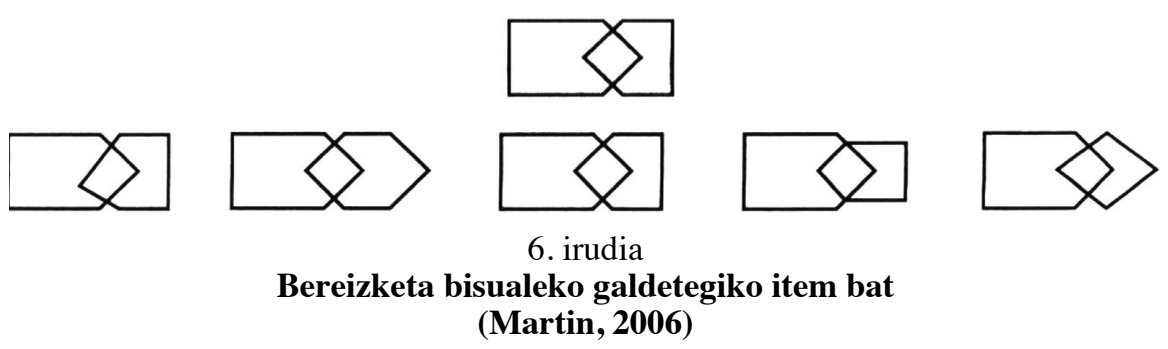


Carroll-en eredu murrizturako (Bickley et al., 1995) erabilitako aldagaiak eta galdetegiak, berriz, ondokoak dira:

1. Itxidura abiadura (CS). Bestelakoa dirudien pertzepzio eremu bat irudi bakar batean lotzeko azkartasuna. Arrietak (2006) sortutako eta balidatutako galdetegia erabili da: osatu gabe dauden irudien identifikazioan datza eta 20 item ditu. Erdi ezabatuta dagoen irudian zer ikusten den esan behar zuen haurrak ahoz.

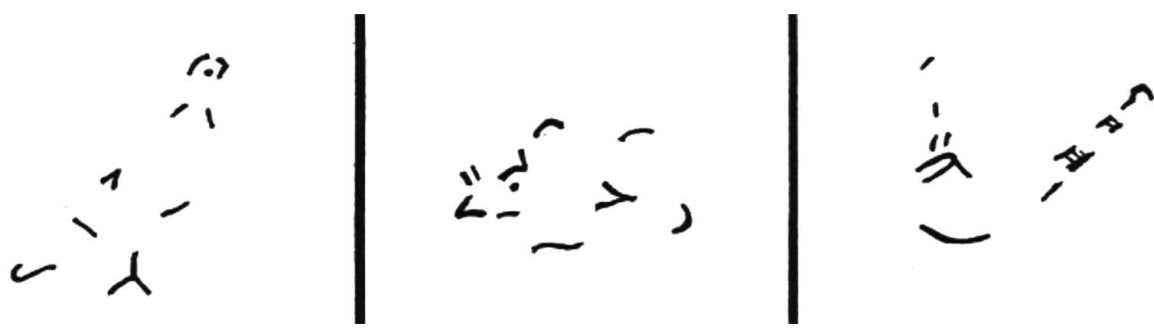

7. irudia
Itxidura abiadurako galdetegiko zenbait item

(Arrieta, 2006)

2. Pertzepzio abiadura (P). Eredu ezagun bat aurkitzeko azkartasuna. Bereizketa Bisualean aipatutako galdetegia erabili da.

\subsection{Prozedura}

Ikasleen adina kontuan hartuta (5-6 urte) ez zitzaien denbora jakin bat utzi lehenengo lau galdetegiak egiteko. Hau da, gehienak, galdetegi bat bukatutakoan, hurrengora pasatzen ziren. Norbaitek ez bazuen amaitzen, jarduera zegoen lekuan uzteko eta hurrengoarekin jarraitzeko eskatzen zitzaion. Lau galdetegi horiek aldi berean pasatu ziren talde osoan, eta gela bakoitzean ordubete inguruko iraupena izan zuen.

Azken bi galdetegiak bakarka pasa ziren. Ikasle bakoitzarekin $10 \mathrm{mi}-$ nutu inguru behar izan ziren bi galdetegiak betetzeko.

\subsection{Datuen analisia}

Kalkulu guztiak SPSS programa estatistikoarekin egin dira.

Haur Hezkuntzako ikasleen ahalmen espaziala neurtzeko, Frostig eta Horne-ren (1964) eredu egokituan oinarrituta, hurrengo formula erabili da, 
galdetegi bakoitzean lortutako puntuazioa 100era haztatu ondoren (ahalmen espazialean lor daitekeen puntuazioa, gehienez, 100 izanik):

$$
\text { Ahalmen espaziala }(1)=(I H P+C F+E P P+E E P+B B) / 5
$$

Bestetik, Carroll-en bi faktoreko eredu murriztuari dagokionez, Bereizketa bisualeko $(B B)$ eta Itxidura abiadurako $(C S)$ galdetegietan lortutako puntuazioak 100era haztatu dira. Eta, beraz, Carroll-en eredu murriztuan oinarritutako ahalmen espaziala neurtzeko ondoko formula erabili da (puntuazio maximoa 100 izanik):

Ahalmen espaziala $(2)=(C S+B B) / 2$

\section{EMAITZAK ETA INTERPRETAZIOA}

\subsection{Haur Hezkuntzako ikasleen ahalmen espazialaren eredu teorikoa zehazten}

Lan honen helburu nagusiari helduko diogu lehendabizi. Horretarako, bi ereduekin lortutako emaitzak konparatuko ditugu eskala berdinean jarriz eta bietan lor daitekeen puntuazio maximoa berbera izanik: 100 puntu. Ondokoak dira ahalmen espazialean lortutako puntuazioen batezbestekoa eta desbideratze tipikoa eredu bakoitzean:

2. taula

Eredu bakoitzarekin lortutako estatistikoak

\begin{tabular}{lccc}
\hline \multicolumn{1}{c}{ Ahalmen espaziala } & $N$ & $\bar{X}$ & $\sigma$ \\
\hline 1. (Frostig-Horne egokitua) & 96 & 58,48 & 9,72 \\
2. (Carroll murriztua) & 97 & 25,71 & 9,62 \\
\hline
\end{tabular}

Taulan ikusten denez, Frostig-Horne-ren eredu egokituari dagokion ahalmen espazialeko puntuazioen batezbestekoa Carroll-en eredu murriztuari dagokiona baino altuagoa da. Baina helburuetan azaldu dugun moduan, interesatzen zaiguna Haur Hezkuntzako ikasleen ahalmen espaziala neurtzeko bi ereduetatik eraginkorrena zein den ezagutzea da, ahalmen espazialaren edozein azterketa burutzeko eredu teoriko finkoa ezartzea garrantzitsua delako.

Hala ere, eskolako eguneroko praktikan gehien interesatzen dena honakoa da, ikasle batek ahalmen espazial altua, normala edo baxua duen jakitea, laguntza eskaini behar zaion ala ez erabakitzeko. Beraz, ildo horri hel- 
duz eta 2. taulako datuak kontuan hartuta, bi aldagaiak birkodetu ditugu ondoko moduan:

— Maila baxua: «ahalmen espaziala $\leq \bar{X}-\sigma$ » betetzen dutenei 1 balioa eman zaie.

- Maila normala: $\langle\bar{X}-\sigma<$ ahalmen espaziala $\leq \bar{X}+\sigma »$ betetzen dutenei 2 balioa eman zaie.

- Maila altua: «ahalmen espaziala $>\bar{X}+\sigma$ » betetzen dutenei 3 balioa eman zaie.

Hezkuntza praktikan ohikoa da horrelako mailakatzeak egitea, horrek ikasleari laguntza eskaini behar zaion ala ez erabakitzeko nahikoa informazio ematen duelako.

Aurretik esan bezala, ikasle bakoitzak bi ereduetako galdetegietan lortutako puntuazioekin aldagai berriak sortu dira, puntuazio horiek aipatutako hiru mailatan banatuz. Modu horretan, bi aldagai berri horien artean desberdintasun esanguratsurik ba ote dagoen ikusiko dugu eta, horrela, aurreko baieztapena (bi ereduak baliokideak direla) ziurtatzen den ala ez erabaki ahal izango dugu.

Horretarako, lehendabizi, aldagai berriek banaketa normalari jarraitzen dioten ikusi behar da. Ondoko taulan ikus daitezke Kolmogorov-Smirnov proban lortutako emaitzak:

3. taula

Aldagai berrien Kolmogorov-Smirnov probako emaitzak

\begin{tabular}{lcc}
\hline Ahalmen espazial birkodetua & $Z$ & $p$-balioa \\
\hline 1. (Frostig-Horne egokitua) & 4,031 & 0,000 \\
2. (Carroll murriztua) & 3,660 & 0,000 \\
\hline
\end{tabular}

Taulan ikusten denez, birkodetutako bi aldagai berriek ez diote banaketa normalari jarraitzen. Ondorioz, bi ereduak baliokideak diren frogatzeko, eta bi laginak erlazionaturik daudenez, heinen zeinuen Wilcoxon proba erabili da.

4. taula

Birkodetutako bi aldagaien arteko Wilcoxon proba

\begin{tabular}{llc}
\hline \multicolumn{1}{c}{ Ahalmen espaziala } & $Z$ & $p$-balioa \\
\hline 1. (Frostig-Horne egokitua) & 1,177 & 0,239 \\
2. (Carroll murriztua) & & \\
\hline
\end{tabular}


Taulan ikus daitekeenez, birkodetutako datuak kontuan hartuta ez dago desberdintasun esanguratsurik bi ereduen artean $(p>0,05)$. Ondorioz, bi ereduak estatistikoki baliokideak dira.

Beraz, bi ereduak baliogarriak dira Haur Hezkuntzako ikasleen ahalmen espaziala neurtzeko eta aztertzeko. Hala ere, guk bietatik Carroll-en eredu murriztua proposatzen dugu 5-6 urteko ikasleen ahalmen espazialaren neurketarako, bost faktoreko ereduarekin alderatuz, lan praktikoa aurreztea ahalbidetuko duelako.

\subsection{Nesken eta mutilen arteko desberdintasunak ahalmen espazialean}

Bigarren helburuari dagokionez, ikus dezagun ea Haur Hezkuntzako ikasleen ahalmen espazialean ba ote dagoen sexuen arteko desberdintasunik.

Horretarako, lehendabizi, bi aldagaiek banaketa normalari jarraitzen diotela ziurtatuko dugu, Kolmogorov-Smirnov proba burutuz; ondoko emaitzak lortu dira (ikus 5. taula). Ikusten denez, bi aldagaiek banaketa normalari jarraitzen diote $(p>0,05)$.

5. taula

Kolmogorov-Smirnov probako emaitzak

\begin{tabular}{lccc}
\hline \multicolumn{1}{c}{ Ahalmen espaziala } & $Z$ & $p$-balioa \\
\hline 1. (Frostig-Horne egokitua) & 0,917 & 0,369 \\
2. (Carroll murriztua) & 0,649 & 0,793 \\
\hline
\end{tabular}

Ondorioz, sexuen arteko desberdintasun posibleak aztertzeko $t$ proba erabili da:

6. taula

Sexuen arteko t probak eredu bakoitzean

\begin{tabular}{l|cccc|cc}
\hline \multicolumn{1}{c|}{ Ahalmen espaziala } & Sexua & $N$ & $\bar{X}$ & $\Sigma$ & $t$ & $p$-balioa \\
\hline \multirow{2}{*}{ 1. (Frostig-Horne egokitua) } & Mutilak & 52 & 57,69 & 10,10 & $-0,871$ & 0,386 \\
& Neskak & 44 & 59,42 & 9,28 & & \\
\hline \multirow{2}{*}{ 2. (Carroll murriztua) } & Mutilak & 53 & 24,35 & 7,93 & $-1,411$ & 0,162 \\
\hline
\end{tabular}

Ikusten den moduan ez dago desberdintasun esanguratsurik, ez Frostig eta Horne-ren ereduaren kasuan ezta Carroll-en eredu murriztuan ere.

Orain, bi ereduetako gaitasunak banaka aztertuko dira. Horretarako, aldagaiek banaketa normalari jarraitzen dioten ala ez ikusiko da. 
7. taula

Kolmogorov-Smirnov probako emaitzak

\begin{tabular}{lccc}
\hline \multicolumn{1}{c}{ Bi ereduetako gaitasunak } & $Z$ & $p$-balioa & $\begin{array}{c}\text { Banaketa } \\
\text { normala }\end{array}$ \\
\hline Irudi-hondoaren pertzepzioa & 1,937 & 0,001 & $\mathrm{Ez}$ \\
Iraunkortasun pertzeptuala & 0,996 & 0,274 & $\mathrm{Bai}$ \\
Espazioko posizioaren pertzepzioa & 2,441 & 0,000 & $\mathrm{Ez}$ \\
Erlazio espazialen pertzepzioa & 2,171 & 0,000 & $\mathrm{Ez}$ \\
Pertzepzio-abiadura (P) & 1,496 & 0,023 & $\mathrm{Ez}$ \\
Itxidura abiadura (CS) & 0,870 & 0,435 & $\mathrm{Bai}$ \\
\hline
\end{tabular}

Taulan ikusten den moduan Iraunkortasun pertzeptualak eta Itxidura abiadurak banaketa normalari jarraitzen diote eta, beraz, sexuen arteko desberdintasunak aztertzeko, $\mathrm{t}$ probak erabili dira gaitasun horietan (ikus 8. taula). Beste aldagaiek banaketa normalari jarraitzen ez diotenez, MannWhitney probak erabili dira (ikus 9. taula). Ikus ditzagun lortutako emaitzak:

\section{8. taula}

Sexuen arteko t probak

\begin{tabular}{|c|c|c|c|c|c|c|}
\hline $\begin{array}{l}\text { Bi ereduetako } \\
\text { gaitasunak }\end{array}$ & Sexua & $N$ & $\bar{X}$ & $\sigma$ & $t$ & $p$-balioa \\
\hline Iraunkortasun pertzeptuala & $\begin{array}{l}\text { Mutilak } \\
\text { Neskak }\end{array}$ & $\begin{array}{l}52 \\
44\end{array}$ & $\begin{array}{l}10,38 \\
11,07\end{array}$ & $\begin{array}{l}3,04 \\
3,24\end{array}$ & $-1,064$ & 0,290 \\
\hline Itxidura abiadura (CS) & $\begin{array}{l}\text { Mutilak } \\
\text { Neskak }\end{array}$ & $\begin{array}{l}53 \\
44\end{array}$ & $\begin{array}{l}4,43 \\
5,16\end{array}$ & $\begin{array}{l}2,34 \\
2,75\end{array}$ & $-0,402$ & 0,164 \\
\hline
\end{tabular}

9. taula

Sexuen arteko Mann-Whitney probak

\begin{tabular}{l|ccc|ccc}
\hline \multicolumn{1}{c|}{ Bi ereduetako gaitasunak } & Sexua & $N$ & Mediana & $U$ & $Z$ & $p$-balioa \\
\hline \multirow{2}{*}{ Irudi-hondoaren pertzepzioa } & Mutilak & 52 & 45,79 & 1003,0 & $-1,054$ & 0,292 \\
& Neskak & 44 & 51,70 & & & \\
\hline \multirow{2}{*}{ Espazioko posizioaren pertzepzioa } & Mutilak & 52 & 50,40 & 1045,0 & $-0,761$ & 0,447 \\
& Neskak & 44 & 46,25 & & & \\
\hline \multirow{2}{*}{ Erlazio espazialen pertzepzioa } & Mutilak & 52 & 47,63 & \multirow{2}{*}{1098,5} & $-0,344$ & 0,731 \\
& Neskak & 44 & 49,53 & & & \\
\hline \multirow{2}{*}{ Pertzepzio abiadura (P) } & Mutilak & 53 & 48,46 & 1137,5 & $-0,209$ & 0,834 \\
\hline
\end{tabular}


Tauletan ikus daitekeenez, ez dago inolako desberdintasun esanguratsurik ahalmen espazialeko gaitasun bakoitzean.

Marko teorikoan ikusi dugu emaitza kontrajarriak daudela azken urteetako ikerketetan, baina lan honetan ikusi da ez dagoela aztertutako Haur Hezkuntzako ikasleen ahalmen espazialean inolako desberdintasunik mutilen eta nesken artean, ezta gaitasunak bakarka aztertuta ere.

\section{ONDORIOAK}

Ikerketa honetan Haur Hezkuntzako ikasleen (5-6 urte) ahalmen espazialaren eredu teoriko bat proposatu nahi izan da. Horretarako, Carroll-ek (1993) adimena osatzen duten gaitasun guztien inguruan egindako ikerketa garrantzitsutik abiatu gara; autoreak analisi faktorialaren bidez frogatu zuen ahalmen espaziala adimena osatzen duten 8 faktore independenteetariko bat dela, eta ahalmen espaziala, aldi berean, beste 5 faktore independenteetan banatzen dela egiaztatu zuen.

Ahalmen espazialaren eredu horretan oinarritutako galdetegiak, hala ere, 11-12 urtetik aurrerako ikasleek egiteko modukoak dira. (Arrieta, 2006). Bickley et al. (1995) autoreek, aldiz, bost galdetegi horietatik bi soilik erabili zituzten 12 urte baino gutxiagoko ikasleen ahalmen espaziala aztertzeko. Gure ikerketa honetan, Carroll-en eredu murriztu hori Haur Hezkuntzako ikasleen (5-6 urte) ahalmen espazialaren eredu teoriko finkoa izan zitekeen ala ez aztertu nahi izan dugu.

Horretarako, marko teorikoan ikusi bezala, ikerketa ugariren azterketa egin da, xehetasunez ahalmen espaziala osatzen duten gaitasunak aztertuz. Bide horretan, Frostig eta Horne-k (1964) zehaztutako eredutik Hoffer-ek (1977) egokitutako zazpi gaitasuneko eredua hartu da aintzat. Hortik abiatuta, bost gaitasuneko beste eredu bat proposatu dugu («Frostig eta Horne egokitua» deitu dioguna).

Beraz, lanaren helburu nagusia Haur Hezkuntzako ikasleen ahalmen espazialaren eredu teorikoa zehaztea izanik, aurretik aipatutako bi eredu horien arteko erlazioa aztertu nahi izan dugu. Emaitzetan ikusi dugun bezala, bi ereduak estatistikoki baliokideak dira eta, beraz, biak dira baliagarriak 5-6 urteko ikasleen ahalmen espaziala neurtzeko. Hala ere, aurretik aipatu dugun bezala, bietatik Carroll-en eredu murriztua aukeratu da, bi faktoreko eredua izanik, soilik bi galdetegi pasatuta («itxidura abiadurarena» eta «bereizketa bisualarena») ikasleen ahalmen espaziala neurtzeko aukera dagoelako. Galdetegi horiek aplikatzeko erraztasunak informazio baliagarria lortzea ahalbidetuko du; informazio horri erabilpen egokia ematen bazaio, ingurunearen eta, beraz, geometriaren ezagutza aberasgarriagoa lortzeko bidea irekiko du. Gainera, ikasleen ahalmen espaziala hobetzeko helburuarekin sortutako esku-hartze didaktiko esanguratsuak proposatzeko ere baliabide baliagarria izan daiteke. 
Enpirikoki egiaztatutako eredu horrekin, ikertzaile askok azpimarratutako hutsunea bete nahi da, eta aurreko eta ondorengo ikerketak aztertzeko, konparatzeko eta erreplikatzeko aukera ematea du helburu.

Bestalde, aukeratutako lagineko ikasleen ahalmen espazialean egon daitezkeen sexu desberdintasunak ere aztertu nahi izan ditugu.

Aurretik aipatu den bezala, ikerketa ugarik baieztatu dituzte mutilen aldeko desberdintasunak ahalmen espazialean edota bere faktoreetako batean. (Battista, 1990; Linn eta Petersen, 1985; Maccoby eta Jacklin, 1974). Hala ere, emakumearen presentzia hezkuntzan eta lan munduan geroz eta handiagoa den heinean, desberdintasun horiek desagertuz joan dira, azken urteetako hainbat ikerketak baieztatu duten moduan. (Arrieta, 2006; Frick, Hansen eta Newcombe, 2013; Lehmann, Jansen eta Quaiser-Pohl, 2014).

Haur Hezkuntzako ahalmen espazialean zentratuz, emaitza kontrajarriak aurki daitezke: batzuek desberdintasunik ez dagoela ziurtatzen duten arren (Möhring eta Frick, 2013; Schwarzer, Freitag, Buckel eta Lofruthe, 2013), beste ikertzaile batzuek mutilen aldeko desberdintasunak antzeman dituzte (Quinn eta Liben, 2014).

Ikusten denez, emaitza horiek guztiak ez datoz bat eta horren arrazoia ahalmen espazialaren eredu teoriko finko baten falta izan daiteke. Ikerketa askotan gaitasunak bakarka aztertzen dira, ahalmen espazialaren egituran duten kokalekua zehaztu gabe, eta horrek ikerketa desberdinen emaitzak konparatzea eragozten du.

Hori dela-eta, guk lehendabizi eredu teorikoa finkatu dugu eta, ondoren, sexu desberdintasun posibleak aztertu ditugu. Emaitzetan ikusi dugun moduan, ez dugu inolako desberdintasunik antzeman, ez aztertutako bi ereduetan oinarritutako ahalmen espazialeko puntuazioetan, ezta galdetegi bakoitzeko puntuazioetan ere. Beraz, emaitza horrek berresten du azken hamarkadako joera, ahalmen espazialean sexu desberdintasunik ez dagoela, alegia.

\section{ERREFERENTZIAK}

Arrieta, M. (2006). La capacidad espacial en la educación matemática: estructura y medida. Educación Matemática, 18(1), 125-158.

Battista, M. T. (1990). Spatial visualization and gender differences in high school geometry, Journal for Research in Mathematics Education, 21(1), 47-60.

Bickley, P.G., Keith, T. Z., eta Wolfle, L. M. (1995). The three-stratum theory of cognitive abilities: Test of the structure of intelligence across the life span. Intelligence, 20, 309-328.

Bishop, A. J. (1983). Space and geometry. In R. Lesh, \& M. Landau (eds.), Adquisition of mathematics concepts and processes (pp. 175-203). New York: Academic Press.

Canals, M. A. (1997). La geometría en las primeras edades escolares. Suma, 25, 31-44. 
Carroll, J. B. (1993). Human cognitive abilities. Cambridge: University Press.

Clements, D. H., Battista, M. T., Sarama, J., eta Swaminathan, S. (1997). Development of students' spatial thinking in a unit on geometric motions and area. The Elementary School Journal, 98, 171-186.

Cunningham, S. A., eta Reagan, C. L. (1972). Handbook of visual perceptual training. Springfield, IL: Charles C. Thomas Publisher.

Cheng, Y. L. eta Mix, K. S. (2014). Spatial training improves children's mathematics ability. Journal of Cognition and Development, 15, 2-11.

Del Grande, J. J. (1987). Spatial perception and primary geometry. Learning and Teaching Geometry, K-12, 126-135.

Frick, A., Hansen, M. A., eta Newcombe, N. S. (2013). Development of mental rotation in 3- to 5-year-old children. Cognitive Development, 28(4), 386-399.

Frostig, M. (1988). Test de desarrollo de la percepción visual. Madrid: TEA.

Frostig, M., eta Horne, D. (1964). The Frostig Program for the development of visual perception. Chicago: Follett Publishing Co.

Ganley, C. M., Vasilyeva, M. eta Dulaney, A. (2014), Spatial Ability Mediates the Gender Difference in Middle School Students' Science Performance. Child Development, 85, 1419-1432.

Goldsmith, L. T., Hetland, L., Hoyle, C., eta Winner, E. (2016). Visual-spatial thinking in geometry and the visual arts. Psychology of Aesthetics, Creativity, and the Arts, 10(1), 56-71.

Gunderson, E. A., Ramirez, G., Beilock, S. L., eta Levine, S. C. (2012). The relation between spatial skill and early number knowledge: The role of the linear number line. Development Psychology, 48(5), 1229-1241.

Gutiérrez, A. (1991). La investigación en didáctica de las matemáticas. In A. Gutiérrez (arg.), Área de conocimiento Didáctica de la Matemática, colección «Matemáticas: Cultura y aprendizaje», 1 (pp. 149-194). Madrid: Síntesis.

Hawes, Z., Moss, J., Caswell, B., eta Poliszczuk, D. (2015). Effects of mental rotation training on children's spatial and mathematics performance: A randomized controlled study. Trends in Neuroscience \& Education, 4, 60-68.

Hoffer, A. R. (1977). Mathematics resource project. Geometry and visualization. Palo Alto: Creative Publications.

Kell, H. J., Lubinski, D., Benbow, C. P., eta Steiger, J. M. (2013). Creativity and Technical Innovation: Spatial Ability's Unique Role. Psychological Science, 24(9), 1831-1836.

Lauer, J. E. eta Lourenco, S. F. (2016). Spatial processing in infancy predicts both spatial and mathematical aptitude in childhood. Psychological Science, 27(10), 1291-1298.

Lauer, J. E., Udelson, H. B., Jeon, S. O., eta Lourenco, S. F. (2015). An early sex difference in the relation between mental rotation and object preference. Frontiers in Psychology, 6, 1-8.

Lehmann, J., Jansen, P., eta Quaiser-Pohl, C. M. (2014). Correlation of motor skill, mental rotation, and working memory in 3- to 6-year-old children. European Journal of Developmental Psychology, 4, 1-14.

Linn, M. C., eta Petersen, A. C. (1985). Emergence and characterization of sex differences in spatial ability: A meta-analysis. Child Development, 56, 1479-1498.

Maccoby, E. E., eta Jacklin, C. N. (1974). The Psychology of Sex Differences. Stanford: University press. 
Maris, S., eta Noriega, M. (2010). La competencia espacial. Evaluación en alumnos de nuevo ingreso a la universidad. Educación Matemática, 22(2), 65-91.

Martin, N. (2006). Test of visual perceptual skills. USA: Academic Therapy Publications.

Martin, M. O., Mullis, I. V. S., eta Stanco, G. M. (2012). TIMSS 2011 international results in science. Chestnut Hill, MA: TIMSS \& PIRLS International Study Center, Boston College.

Mix, K. S. eta Cheng, Y. L. (2012). The relation between space and math: Developmental and educational implications. In J. B. Benson (arg.), Advances in child development and behavior, 42 (pp. 197-243). San Diego, CA: Academic Press.

Möhring, W., eta Frick, A. (2013). Touching up mental rotation: effects of manual experience on 6-month-old infants' mental object rotation. Child Development, 84(5), 1554-1565.

NCTM (2000). Curriculum and evaluation standards for school mathematics. Reston, VA: NCTM.

Newcombe, N. S. (2010). Picture this: Increasing math and science learning by improving spatial thinking. American Educator, 34, 29-35, 43.

Piaget, J. (1954). The construction of reality in the child. New York: Basic Books.

Quinn, P. C., eta Liben, L. S. (2014). A sex difference in mental rotation in infants: convergent evidence. Infancy, 19, 103-116.

Sarasua, J. (2010). Hacia una categorización de los objetivos geométricos. Propuesta de nuevos descriptores de los niveles de Van Hiele para la representación externa de figuras planas (Tesis doctoral). Euskal Herriko Unibertsitatea, Euskal Herria.

Schwarzer, G., Freitag, C., Buckel, R., eta Lofruthe, A. (2013). Crawling is associated with mental rotation ability by 9 -month-old infants. Infancy, 18, 432441.

Tartre, L. A. (1990). Spatial orientation skill and mathematical problem solving. Journal for Research in Mathematics Education, 21(3), 216-229.

Uttal, D. H., Meadow, N. G., Tipton, E., Hand, L. L., Alden, A. R., Warren, C., eta Newcombe, N. S. (2013). The malleability of spatial skills: a meta-analysis of training studies. Psychological Bulletin, 139, 352-402.

Uttal, D. H., Miller, D. I., eta Newcombe, N. S. (2013). Exploring and Enhancing Spatial Thinking: Links to Achievement in Science, Technology, Engineering, and Mathematics? Current Directions in Psychological Science, 22(5), 367373.

Verdine, B. N., Golinkoff, R. M., Hirsh-Pasek, K., eta Newcombe, N. S. (2014). Finding the missing piece: blocks, puzzles, and shapes fuel school readiness. Trends in Neuroscience and Education, 3(1), 7-13.

Vereecken, P. (1961). Spatial development. Constructive praxia from birth to the age of seven. Groninga: J. B. Wolters.

Vurpillot, E. (1976). The visual world of the child. London: George Allen \& Unwin. 